\title{
Dynapak による高密度粉末成形について
}

\author{
浅村均*.田中司*.由中 武*
}

\section{Iまえがき}

最近, 高圧ガスの炬熱膨張のエネルギーを利用した “Pneumatic Mechanical Machine" の開発が盛んに 行なわれ，Dynapak をはじめとして種々の商品名で呼 ばれるむのが市販されている。この種の機械ば多くの特 徵を持ち，鍛造や押出しの分野では，すでに，工業的な

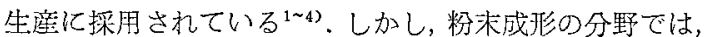
この種の機械の応用はまだ実験的あるいは試作的な段階 で，その詳細なデー夕あ公表されていない状況である。

最近の僋向として，徒来の低，中密度の焼結機械部品 にかわって高密度部品の開発が積極的に行なわれている。 すなわち，自動車工栄その他加らの需要娄次第に衙摹的 な荷重の加わる部品に及び，従来の鋳釾造部品の焼結 部品への切りかえに対する要望が年々虺くなってきてい る、これはむちろん粉末治全法の高能率な製造法による コストが安い点と，材質的な面で十分に信頼できる部品 の製造が可能になる見通しが得ら杖つあるととによる 子思吅机る。

従来から行なわれてきた高密度呰綕部品の製造工程は 原料鉄粉も圧縮性の上い，たとえば電解鉄粉の上うな子 のを配合するとか，あるいは二重坐繀，二重焼結法をと らなけ机ばならない，したがって高密度のむのが得ら机 るが高価となるのでその使用簌盲む狭牥られるとととな り，庵価作り得る製造工法の開発が望まれるわけであ る.とのような意味で, Dynapak はエネルギーの調節が きわわて容易で，また打撃でとのエネルギ一誤差がきわ めて少なく，高能率に高压力を加讨得る方法としてその 特徵があり，高密度の圧粉体の得ら机ると之，成形性の覀 い粉末む成形できること，大型の部品に適用できるなど の利点があるとされている。しかしはたして Dynapak を粉末成形俰利用するこよが得筑加どうかの一つの目安 を得る目的で，純鉄粉を用いて工業化に苟たっての甚礎 的な諸問題の一部を調查したのでここに報告することに 寸る。

\section{II 実 験 装 置}

使用機械焅 General Dynamics Corp. 製の Dynapak 620D 型で，その主な仕様を表 1 以示す。エネルギ 一源としての高圧ガスは $\mathrm{N}_{2}$ ガスまた柱圧縮空気が用い ら机るが，筆者らは Ingersol-Rand 社製のコンプレッ
サー(最高压 $2300 \mathrm{psi}$ )の空気を用いた. Dynapak の詳

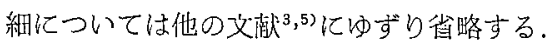

表 1 . Dynapak 620D 型の仕棁

\begin{tabular}{|c|c|}
\hline 最大エネルギー & $40,000 \mathrm{ft}-\mathrm{lbs}(5.5$ ton $-\mathrm{m})$ \\
\hline 規格ストローク & $12^{\prime \prime}(30.5 \mathrm{~cm})$ \\
\hline 最高ガス压力 & $2,000 \mathrm{psi}\left(140 \mathrm{~kg} / \mathrm{cm}^{2}\right)$ \\
\hline 最高ラム速度（相対） & $17 \mathrm{~m} / \mathrm{sec}$ \\
\hline デイライト & $261 / 2^{\prime \prime}$ \\
\hline ダ 1 寸 法 & $12^{\prime \prime} \times 12^{\prime \prime}$ \\
\hline エゼクター能力 & 12 ton \\
\hline エゼクターストローク & $31 / 4^{\prime \prime}$ \\
\hline 1 回打時間 $\left(12^{\prime \prime}\right.$ ストローク) & $6 \mathrm{sec}$ \\
\hline 機械本体寸法 & $55^{\prime \prime} \mathrm{L} \times 19^{\prime \prime} \mathrm{W} \times 132^{\prime \prime} \mathrm{H}$ \\
\hline 機械本体重量 & 4.5 ton \\
\hline
\end{tabular}

使用金型は図1のような構成でダイはタイヤに焼ばめ， あらかじめ压縮応力を加えピーク压力に耐えられるよう にした．パンチには 4 枚のワイヤー・ストレンゲージ

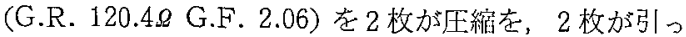
ぱりを受けるようにはりつけて，ブリッジ回路を組九だ。 この出力をプリアンプ（ストレンゲージ・トランスジュ ーサー・ユニット）を通してシンクロスコープで写真測 定した．図2にプリアンプのブロックダイヤグラムを示 す。シンクロスコープのビームの掃引は外部同期により パンチが粉末に接する寸前にマイクロスイッチを押して 掃引を開始するようにした。な枋パンチ荷重とブリッシ 出力の較正は，材料試験機老用い静的に荷重を㞦えて行 なった。また押型渭渆剂としてはステアリン酸还鉊の卜 リクロールエチレン溶液をはけ㴔り後，十分に乾燥して 行なった。

\section{III 圧縮過程について}

Dynapak による粉体の正緛は次の上うにして行なね れる。トリガーするととにより高压ガスが瞬間的に断熱 浢張し，そのエネルギーにより加速されて落下するラム と，まだの反作用として上具するフレームがその間に

* 大阪府立工業奖励会旍金属部 大阪西局区内江，子曷上之町 


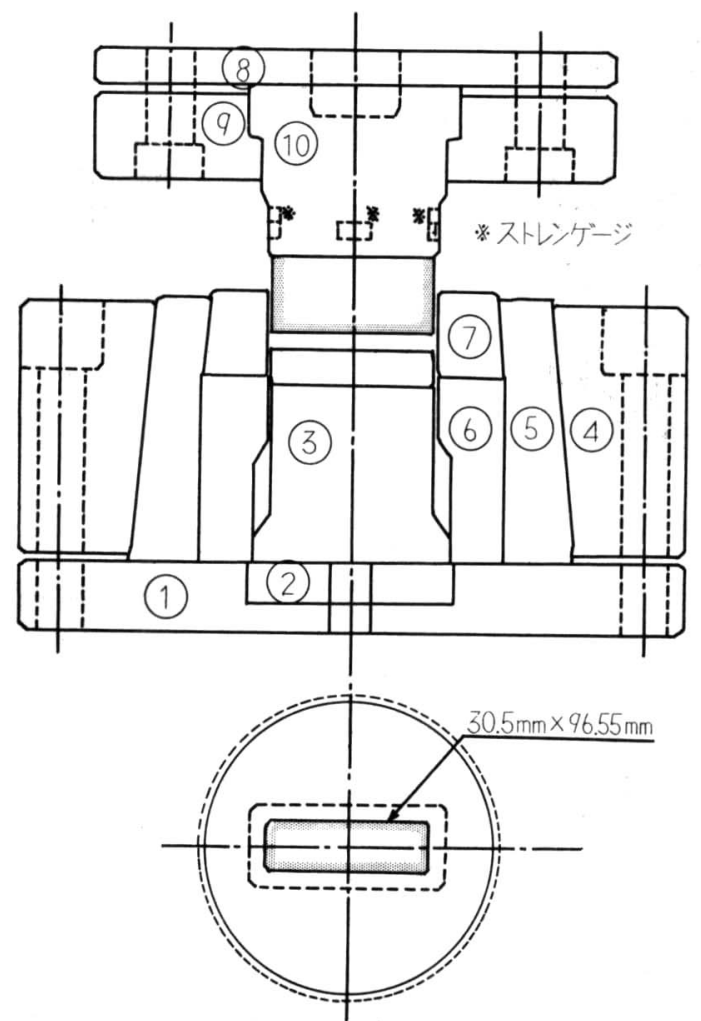
(1)下部スペーサー
(2)ショックプレート
(3)ノックアウトピン
(4)ホルダー
(5)タイヤ
(7)ダイ
(9)パチホルダー
(6)インサートダイ
(8)上部スペーサー
(10)パンチ

図 1 金型の構 成

パンチとダイを介して衝突し, ダイキャビティ中の粉体 の成形が行なわ机る。この場合のパンチに作用する荷重 の時間的な変化は図 3 亿示したような曲線になる. 図 3 で、はパンチが粉末に接触する寸前にシンクロスコープ のビームが掃引を開始した点であり， b 点でちょうどパ ンチが粉末に接し压縮が開始される。圧縮初期に书ける 粒の移動により空陌が減少していく過程ではエネルギー の消費は僅少で，大部分のエネルギーは粒の弾性 および塑性変形過程で消費さ机ると考えられるの で, ラムとフレームの相対速度は街突寸前の最大 速度加ら粉体の圧縮によって徐々に速度を減じ, ついで急激に減じて荷重一時間線図のピーク ( c ) のとてろで速度は零となる。つぎにバウンドして ラムとフレームの両者は離机始め, 圧粉体とパン チの接触は断たれるが, 再びラムは降下して打撃 を与える．との過程を繰り返すととによって次第 に減衰し最後に両者は静止する。とのハンンマーリ ングは Dynapak では機械の構造上避けられない あので, 金型の寸法精度およびセッティングに十 分注意する必要があると思わ机る. 図 4 は Dyna-

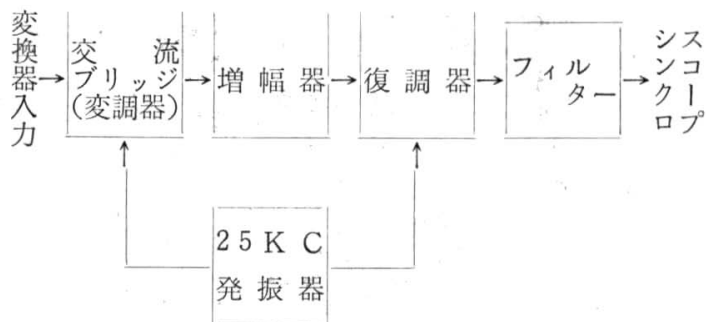

図2 プリアンプのプロックダイヤグラム

pak のハンマーリングを示す荷重一時間線図である.

Dynapak のエネルギーはストロークとファイヤー圧 力によって決定されるが，ストローク一定の場合ファイ ヤ一圧力を徐々に増加してエネルギーを増すと, 荷重一 時間線図は図 5 のごとくピーク荷重が高くなるとともに 圧縮所要時間が短時間側に移行する。図 5 の(e)の例で

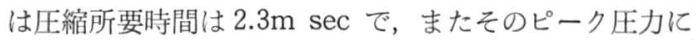
保持される時間は $0.1 \mathrm{~m} \mathrm{sec}$ のオーダーである。なお の衙撃圧縮寸前の速度は約 $8.5 \mathrm{~m} / \mathrm{sec}$ である. こ机は使 用機 $620 \mathrm{D}$ 型の最高速度の約 $1 / 2$, 最大エネルギーの約 $1 / 4$ に相当する.

これらの図は荷重一時間線図であるがこれを荷重一圧 縮距離の線図で考えれば, 前者における加圧速度の速い 初期段階ではその圧縮距離は比較的長く，その後の圧縮 過程の後期では加圧速度が次第に減ずるとともに, 圧縮 距離が短くなるためさらに鋭い立ち上がりを示すはずで ある。すなわち Dynapak を粉末成形使用する場合 は，粉体の圧縮初期のエネルギー消費が少ないために, 圧縮後期に大部分のエネルギーを短い距離で消費すると とになり非常な高圧力が発生するととになる。

\section{IV 供給エネルギーとピーク荷重の関係について}

一定量（230g）の粉末をダイキャビティに入れ，種 々のエネルギーを与えて衝撃圧縮した時に発生するピー ク荷重を設定エネルギーとの関係で求めたのが図 6 であ る. 国産の還元鉄粉 $100 \cdot 24$ および H-100·24に潤滑剂を

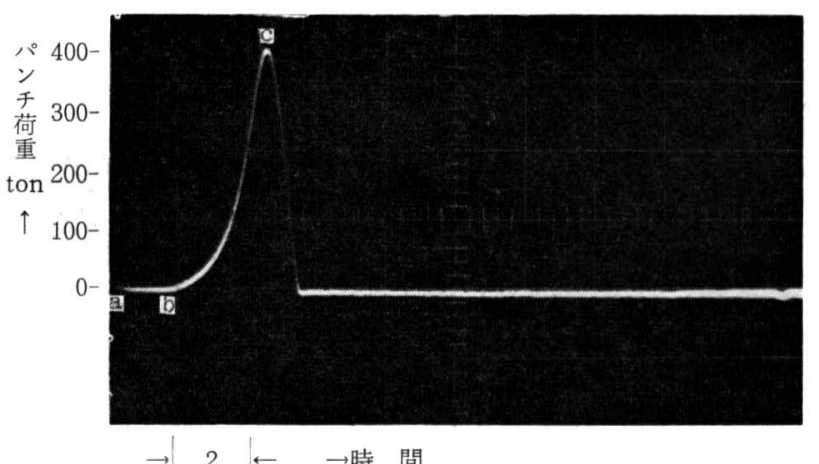

m-sec

図 3 パンチ荷重一時間線図

使用粉末 $: \mathrm{H}-100 \cdot 24+0.5 \%$ Zn st. ファイヤー压力 : $500 \mathrm{psi}$ 


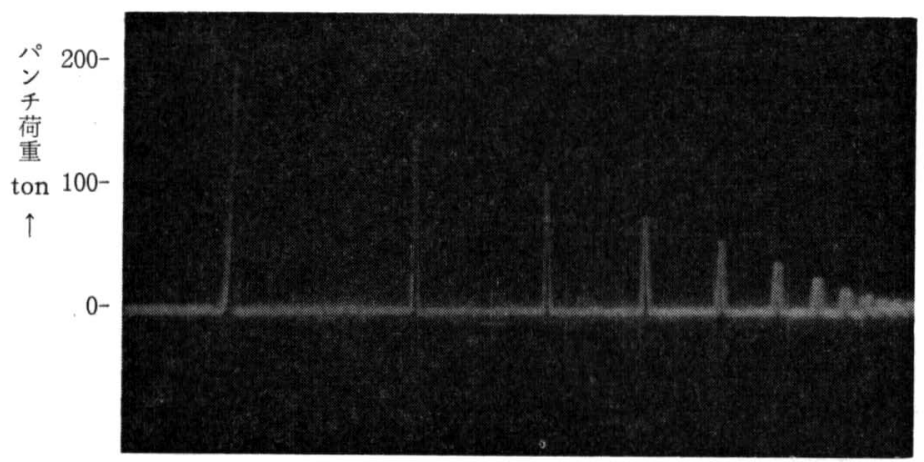

$\rightarrow 20 \mid \leftarrow \rightarrow$ 時 間

図 4 Dynapak のハンマーリング

使用粉末 $: 100 \cdot 24+0.5 \%$ Zn st.

ファイヤー圧力: $275 \mathrm{psi}$

$0.5 \%$ 添加した場合と無添加の場合について求めたもの であるが，エネルギーを増加するとそれぞれほぼ直線的 にピーク荷重は増加する. エネルギーの低いととろでは 鉄粉の差や，潤滑剂添加の有無によってピーク荷重は大 きく変化しないが, 高いエネルギーでは相当な差を生じ る.

Dynapak による粉末成形の工業的利用においては, その金型寿命の見地から設定エネルキ゚ーとピーク荷重の 関係を知ることが非常に重要であると思われる，ピーク
荷重は粉末の諸特性, 潤滑剂の種類, 添加量, 製品の高さなどにより相当に 異なるので，あらかじめピーク荷重を 予測することはかなりの困難を伴う。 しかし設定エネルギーに対してほほ直 線関係にあるとと，および Dynapak はエネルギーの調節が非常に容易で, また打撃ごとのエネルギー誤差が僅少 なため, 十分注意して作業すれば金型 に過大な応力を加えて破壊させるよう なととはないと思われる.なお打撃ご とのピーク荷重の誤差はシンクロスコ ープで写真撮影した荷重一時間線図の 高さのバラッキから計算したところ 2 \%以内であった。

\section{V ピーク荷重と平均荷重について}

粉体の圧縮寸前に Dynapak の持っていた運動のエ ネルギーは圧縮が進むに従って消費される．また一部の エネルギーは金型や機械部分の弾性変形などに消費され る.このエネルギーは成形荷重に依存するものと考えら れる.

今, 全エネルギーが粉体の圧縮中に吸収されると考え ると, 成形中の平均荷重 $(F)$ は次の式によって与えられ る.

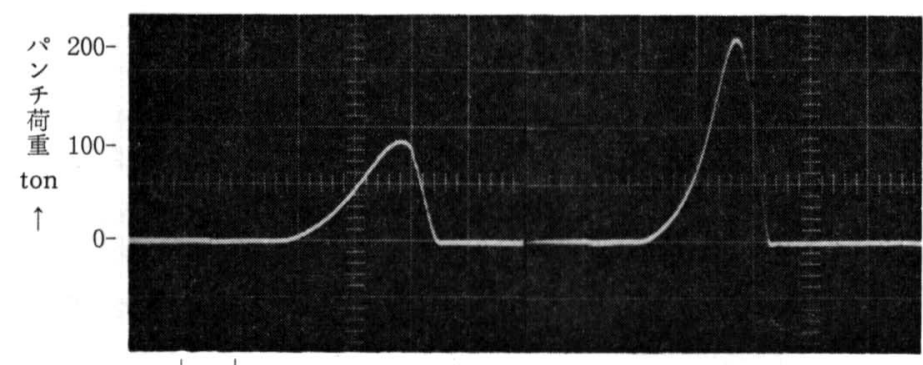

$\rightarrow 2 \leftarrow \rightarrow$ m-sec $\quad$ 時

$\begin{array}{ll}\text { (a) } 145 \mathrm{psi} & \text { (b) } 275 \mathrm{psi}\end{array}$

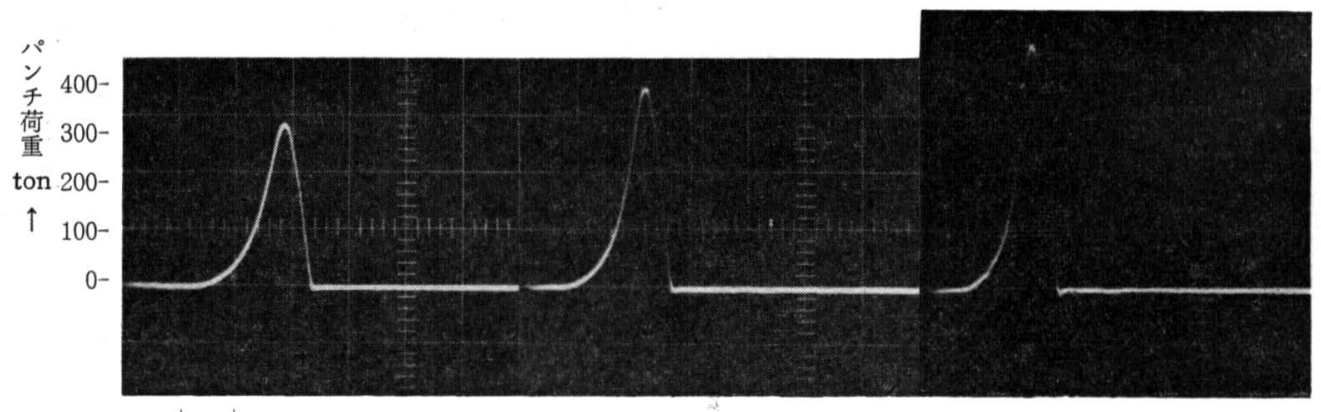

$\rightarrow 2 \mid \leftarrow \rightarrow$ 時 間

m-sec

(c) $415 \mathrm{psi}$

(d) $500 \mathrm{psi}$

(e) $615 \mathrm{psi}$

図 5 パンチ荷重一時間線図 使用粉末 : H-100・24+0.5\% Zn st. 


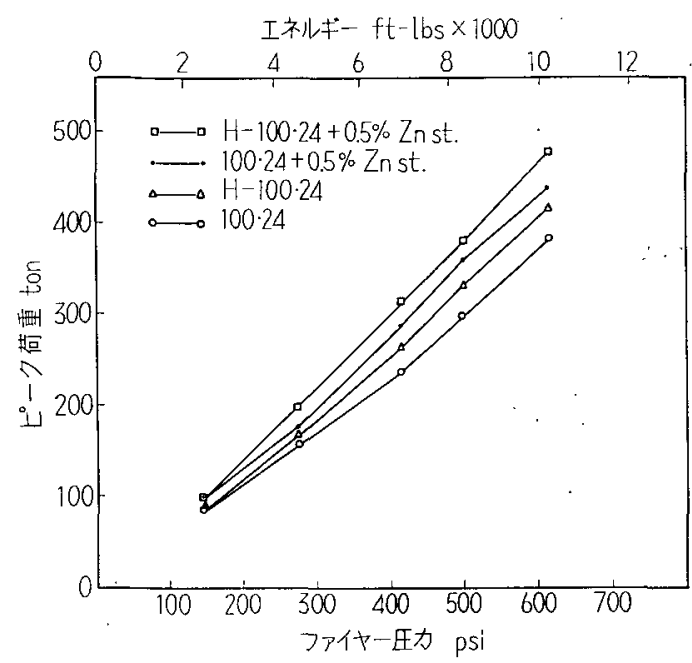

第 6 図 ピーク荷重と供給エネルギー(ファイヤー圧力)の関係

$$
\begin{array}{ll}
\mathrm{F}=\frac{\mathrm{E}}{\mathrm{D}} & \mathrm{E}: \text { エネルギー }(\mathrm{kg}-\mathrm{m}) \\
& \mathrm{D}: \text { 左縮距離 }(\mathrm{mm})
\end{array}
$$

粉末成形のように圧縮初期にあまりエネルギーを要し ない成珍では荷重一王縮量線図は圧縮終期に非常に鋭い ピークを示す。したがって平均荷重とピーク荷重の此は

\begin{tabular}{|c|c|c|c|c|c|}
\hline \multirow{2}{*}{ 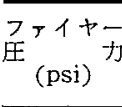 } & \multicolumn{2}{|c|}{ エネルギー } & \multirow{2}{*}{$\begin{array}{c}\text { 平均荷重 } \\
\text { (ton) }\end{array}$} & \multirow{2}{*}{$\begin{array}{c}\text { ピーク荷重 } \\
\text { (ton) }\end{array}$} & \multirow{2}{*}{ 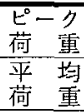 } \\
\hline & (ft-lbs) & $(\mathrm{kg}-\mathrm{m})$ & & & \\
\hline 145 & 2400 & 331.2 & 19.5 & 85 & 4.5 \\
\hline 275 & 4300 & 593.4 & 30.7 & 170 & 5.5 \\
\hline 415 & 6500 & 897.0 & 43.6 & 264 & 6.1 \\
\hline 500 & 8000 & 1104.0 & 52.4 & 332 & 6.3 \\
\hline 615 & 9800 & 1332.0 & 63.2 & 416 & 6.6 \\
\hline
\end{tabular}

表 2 平均荷重とピーク荷重

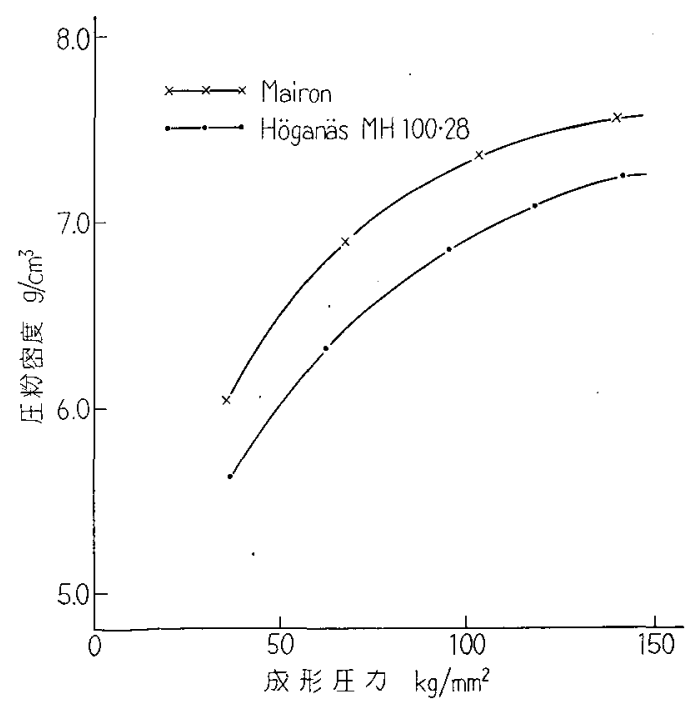

図 7 王粉密度と成形压力の関係
相当に大きな値を持つ．との值は実際作業でおよその成 形荷重を知る場合に参考となるであるう. 表 2 に計算に よって求めた平均荷重と実測のピーク荷重の比を示した。

\section{VI 成形圧力七密度について}

成玥圧力はパンチ荷重を測定している関係で荷重一時 間線図のピーク荷重を試片の嵝面積で除したものでもっ て便宜上表放す，成形圧力と圧粉密度の関係它電解鉄粉

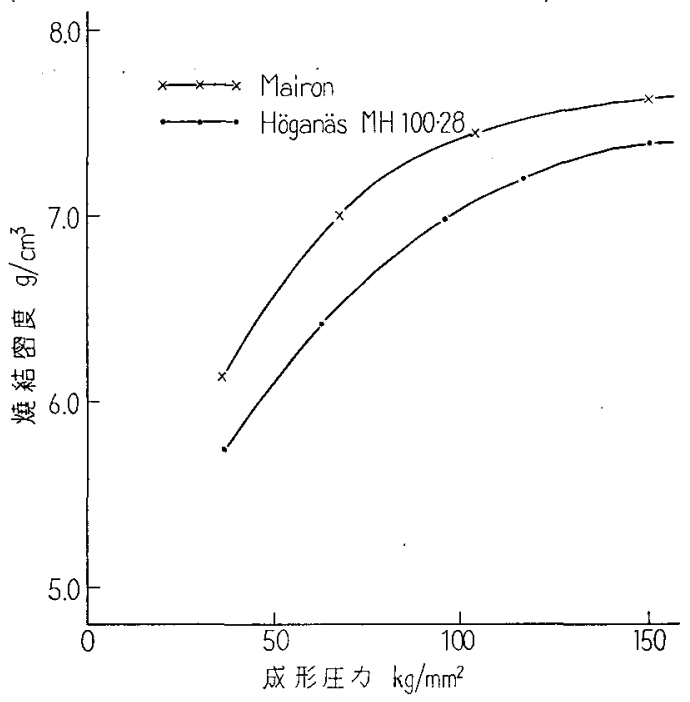

図 8 狫結密度と成形压力の関係

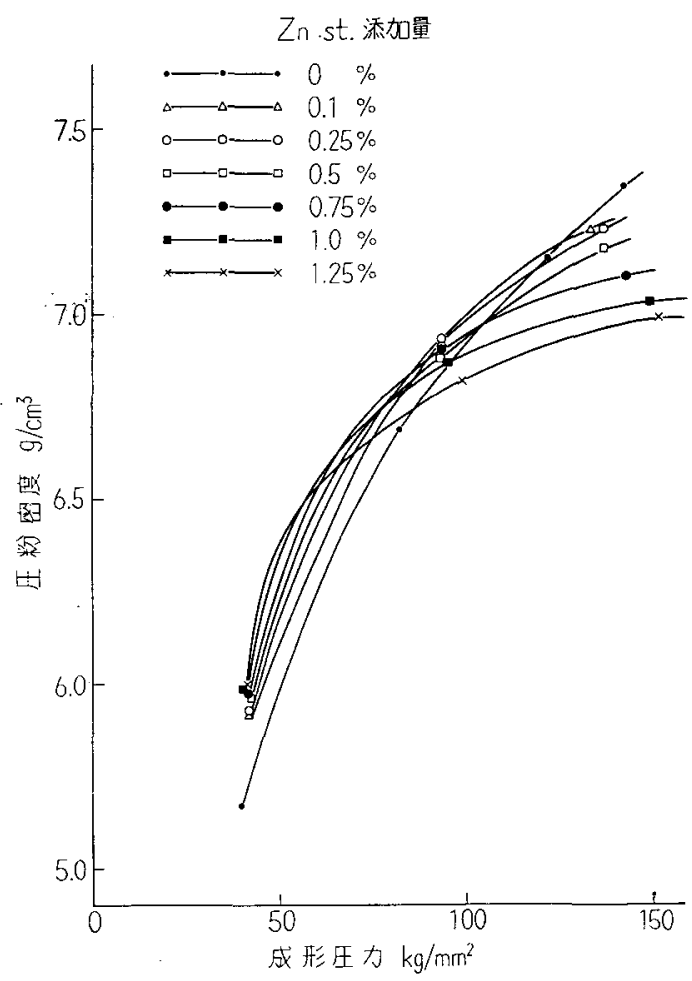

図 9 ステテアリン酸互鉊添加加正粉密度化及ほす影響 
(Mairon) : と還元鉄粉 (Höganäs) について求めたのが 図7である。図8 はこれを $\mathrm{H}_{2}$ 中で $1100^{\circ} \mathrm{C} \times 3 \mathrm{hr}$ 焼結 した後の密度である。

閵滑剂深加の影暨を調べる目的で Höganäs 鉄粉にス テアリン酸亚鉛 $1.25 \%$ まで添加して成班压力之压粉密 度の関係を求めたのが図 9 である。

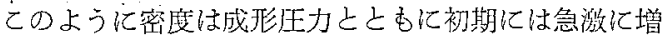
加するが次第にゆるやかになり，つい《は飽和状態に近 づく傾向にある。との㑯向は閵滑剂を多く添加したもの ほど著しく，また到達密度も低くなる。したがって成形 珐力を高くしても密度の向上があまり望めなくなるので， また金型の強度上からの制限をも若え合わせて，おのず 加ら成形圧力には粉末によって適当な限度があると考え られる。

一定エネルギーで成玥した埸合, ピーク荷重仗対し潤 滑剂の添加は低いエネルギーでは大きな影響を持たない が，高いエネルギーでは潤滑剂の添加量の多いほどピー ク荷重高くする。これは潤滑剂が摩擦を減少しエネル ギーの消費を少なくする反面，粉体の間隙を埋めて空気 の脱出を妙害し，圧粉体のより一層の圧緮を因難化する ためと考えられる。

同一エネルギーで成形した埸合の潤滑剂添加量之圧粉 密度は図10のようにエネルギーに応じて最大密度の得ら

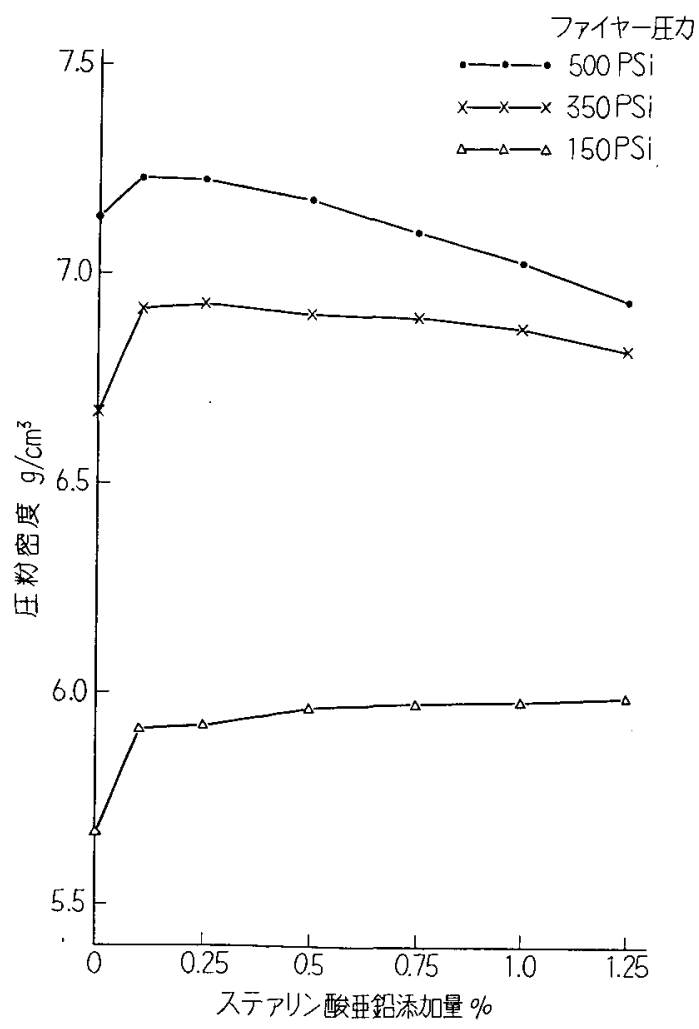

困10非密度とステアリン酸互鉊添加量の関係
れる潤滑剂の最適な添加量がある。またこの最適添加量 は高エネルギーにおけるほど低くなるようである。同様 な笑験を電解鉄粉についてむ行なったが還元鉄汾の場合 には全く見られなかった上面の剝離の問題が起こった。 すなわち無添加および 0.1 \% 添加のむのはうまく成形で きたが，0.25\%以上添加したあのはすべてェネルギーの 高低に関係なくパンチが当たる上面に尿状の剝離が生じ た．この剝離は Dynapak のハンマーリングによって 二度，三度と打揧されるととによって起てったものと考 えられるが，電解鉄粉では形状的に還元鉄粉におりるよ うな王粉体の機械的な粒のからみ合いが少ないとと，お よび潤滑剂が金属接饰を妨げることなどのためであるう。

以上のごとく潤滑剂添加の效果は成形生力の低いとこ ろでは圧縮性を良くするが，高い成形圧力では端効果に なる，低い成形圧力では粉末柆子間㧍よび型壁と粉末間 の摩摖を小さくして流動を助计るが，高い成形圧力では 断熱变环による熱発生で溶融し，粉末粒子間の空気の脱 出を困難にすること，捛よび密度の小さな潤滑剂の入る ことが压粉体の密度の増加を妨げているもの上考えられ る.したがって Dynapak 成形によって高密度製品を 得るためには潤滑剂は添加しない方が好ましいと思われ る。またての方が烧結の際に，潤滑剂添加によって生ず る檤々のトラブルあなく好都合であるだろう。しかしこ の場合には適当な押型潤滑剂の使用が重要な問題となり， 高左之摩擦に耐えらるれ潤滑剂とその均一な㳂布方法の 開発が望まれる。

\section{VII 油圧プレスによる静的な粉末成形との比較に วwT}

(A) 密度

図11は国産の鉄粉（H-100・24）用いて成形圧力之圧 粉密度の関係を比較したものである。図中の静的の場合 は油圧プレスを用い，片押法で徐々に圧縮しその最高圧 に約 $5 \mathrm{sec}$ 保持して成形した場合であり，また動的の場 合は Dynapak による成形で压縮成形時間は数 $\mathrm{m} \mathrm{sec}$ 程度，その最高任に保持される時間は 10 分の数 $\mathrm{m} \mathrm{sec}$ 程度である. 図11より明らかなごとく同じ成形圧力で比 較す机ば，青解的の場合の才が正粉密度は高いが成形圧力 が高くなると，その差は次䈟に少なくなり $150 \mathrm{~kg} / \mathrm{mm}^{2}$ 付近でほぼ等しくなる傾向がある。しかし Dynapakに よる方法はきするひて短時間であるが高压の発生が容易で ある点汇特徴がある上思われる。

Dynapak による粉末成形のように急速な加压速度で， しかもその最高压化保持される時間がきわめて短い場合 に住，粉末精子間任存在する等気の抜け出しが重要な意 味を持つむのと考元られる。乙礼は特に直径に比べて高 さの高い場合代重要となるであろう．大部分の空気は粉 末粒子の間を通って金型の除間加ら脱出するであるうが， 


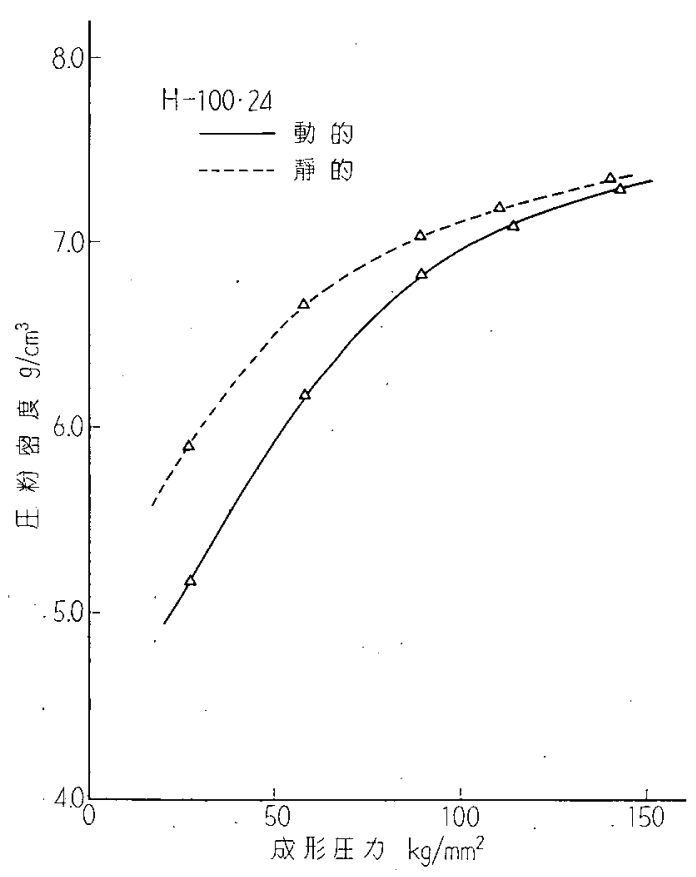

図11 此粉密度と成形圧打の関係の比較

圧縮が進行し空気が閉じ込められればクッションとして 㗢き，その結果粉体の王繀が坊げられるすのと思执れる。 成形正力加高くなるに従って静的之動的の差が少なく なる理由は，動的な場合，型壁と粉末あるいは粉末粒子
相互の摩擦の娍少之断熱变形に上る温度上㫧，さらに八 フマーリングにより温度の上昇した状態で压縮が繰り返 されるととなどが大きく影響しているのではないかと考 える.な括その上に Dynapak の機構的な相打効果屯 見のがせないだろう。

(B) 硬度分布

図12は H-100.24鉄粉索 $142 \mathrm{~kg} / \mathrm{mm}^{2}$ の成形圧力で成 形後 $\mathrm{H}_{2}$ 中で $1100^{\circ} \mathrm{C} \times 3 \mathrm{hr}$ 炡結した試料の縦断面の半 分の Hv 硬度分布を示したすのである。.Dynapak によ る方が均一な硬度分布を示しているが，加圧速度が非常 に速いことが摩擦を減少するとと，および Dynapakの 機構的な相打效果が影響して密度が比較的均一になうた

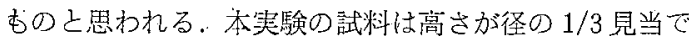
比较的低いが，さらに厚い場合や上下で断面穦の異なる 場合については現在実験を進めている。

\section{䜣 むं す び}

以上 Dynapak による粉末成形の大要を述べたが約 $140 \mathrm{~kg} / \mathrm{mm}^{2}$ の成形压力で成形後, $1100^{\circ} \mathrm{C} \times 3 \mathrm{hr}$ の焼結 で電解鉄粉および還元鉄粉でそれぞれ密度比 97.09 およ び93.99\%が得られること江工業的な高密度粉末成班法乙 して非常に有望な万法であると考えられる。し加しなが ら金型寿命の䦗題やこの方法に適した粉末の特性，䡒結 条件，型設計なよ゙の問題，機構上からくる製品形状への 制約など今後なお検棓すべき問㩆が残されていると思わ れる。

動的

\section{文献}

1) S.A. Skeen: Machinery, 10 (1964), 117.

2) S.A. Skeen: Machinery, 11 (1964), 112.
3）石井，小林：プレス技術，11(1964),69.

4) 山口：塑性と加工，12(1966)，627.

5）田中，和泉，大山：日本金属学会会報，4(1965), 184. 